\title{
Geoglifos paracas en Cerro Ocucaje, Ica, Perú
}

\author{
Paracas Geoglyphs at Cerro Ocucaje, Ica, Peru
}

\author{
Carls William Chuquihuaccha Huancahuari \\ https://orcid.org/oooo-0oo2-2355-9937 \\ Instituto de Paleontología, Arqueología y Medio Ambiente \\ carls.ch.h@gmail.com
}

\section{RESUMEN}

En este artículo se presentan datos inéditos de un Paisaje Arqueológico con presencia de geoglifos figurativos. El estudio sintetiza y discute los resultados fotogramétricos de los resientes hallazgos arqueológicos en Cerro Ocucaje, en el marco del Proyecto Arqueológico Geoglifos de Ica. Durante el período Paracas Tardío (circa 370-200 a. C.) e incluso durante la fase transicional Paracas-Nasca o Nasca Inicial (200 a. C.-90 d. C.), se construyeron figuras sobre laderas de cerros pedregosos de poca elevación, que hasta la actualidad se pueden apreciar como parte del paisaje animado del desierto iqueño.

Palabras clave: Geoglifos; Paracas; Nasca; Horizonte Temprano; Fotogrametría.

\section{ABSTRACT}

This article presents unpublished data from an Archaeological Landscape with the presence of figurative geoglyphs. The study synthesizes and discusses the photogrammetric results of the recent archaeological finds in Cerro Ocucaje, within the framework of the Geoglyphs of Ica Archaeological Project. During the Late Paracas period (about 370-200 BC) and even during the Paracas-Nasca or Initial Nasca 
transitional phase (200 BC-AD 90), figures were built on the slopes of low elevation stony hills, which until today can be appreciate as part of the animated landscape of the Ica desert.

Keywords: Geoglyphs; Paracas; Nasca; Early Horizon; Photogrammetry.

RECibidO: 02/10/2020 - ACEPTAdO: 16/10/2020 - PublicAdo: 25/06/2021

\section{INTRODUCCIÓN}

El término "geoglifo» este concepto formulado originalmente por Kosok y Reiche, suele utilizarse en el contexto arqueológico de diversas maneras, etimológicamente, «el término procede de dos fonemas griegos, geo, tierra y glyphé, carácter o símbolo grabado, que significa literalmente gravados en el suelo» (García, 2013, p. 151). Y aunque algunos investigadores no comparten el término, esta se asocia comúnmente para designar a los geoglifos de la Pampa de Nasca (Lumbreras, 2000, p. 61; Lambers, 2006, p. 20).

Las famosas Líneas y geoglifos de Nasca y Palpa, son los máximos referentes de este tipo de expresión cultural a nivel nacional, se dieron a conocer por Toribio Mejía Xesspe (1939), en el Congreso Nacional de Americanistas, desde entonces muchos investigadores se han interesado por las llamadas marcas del desierto, sin embargo, es a partir de los estudios prolongados del Proyecto Arqueológico Nasca-Palpa, dirigido por Markus Reindel y Johny Isla (1996), donde, «resalta el primer registro científico de geoglifos paracas» (García, 2013, p. 152).

En un contexto local, durante las décadas de los 70, 80 y 90, se realizaron investigaciones significativas de reconocimiento arqueológico, en la parte baja, media y alta del valle de Ica, estas exploraciones consiguieron registrar una gran cantidad de sitios arqueológicos, e informaron de algunos geoglifos en los distritos de San José de Los Molinos, San Juan, La Tinguiña, Santiago y Ocucaje (Williams y Pazos, 1974; Cook, 1988, 1990). Durante más de una década dejaron de documentarse los geoglifos del área de Ica, y recién desde el 2006 han vuelto a circular escasos reportes e informes, donde mencionan la existencia de nuevas figuras en el desierto y valle de Ica (García, 2006; 2013; Chuquihuaccha y Palomino, 2018; Herran, 2018).

Por lo general se asume que los geoglifos de la costa sur, se crearon durante el desarrollo de la cultura Nasca, alrededor del 200 a. C. Sin embargo, las investigaciones vienen demostrando que la tradición inició en el período Paracas Temprano, cerca del 750 a.C. (Reindel e Isla, 2006; Lambers, 2006; García, 2013). Incluso se distinguen motivos de la iconografía chavín en geoglifos de Cerro Lechuza, en Pisco (García, 2013, p. 153-154). La problemática general sobre los Paisajes Arqueológicos de la costa sur de Perú, es que no impera un catastro de sitios arqueológicos, no existe un 
registro total de geoglifos, menos aún de los ubicados en Ica. Los territorios de Nasca y Palpa con frecuencia han sido investigados, y dónde mayor número de geoglifos han sido documentados, sin embargo, reportes aislados en el valle de Ica, vienen sumando una buena cantidad de muestras representativas.

La investigación de las enigmáticas figuras de Cerro Ocucaje, Ica, Perú, nace del interés de conocer la filiación cultural y cronológica, de indagar los modos de manufactura y de los rasgos estilísticos e iconográficos. La investigación se puede definir como un estudio arqueológico de reconocimiento y registro de superficie, sin excavaciones, con soporte técnico en la fotogrametría con sistemas de aeronaves piloteadas a distancia, RPAS, ${ }^{1}$ y en las nuevas tecnologías SIG,${ }^{2}$ que permitió la ubicación satelital de ciertas características inusuales del terreno, y de representaciones geométricas y biomorfas observables.

\section{LOS GEOGLIFOS DE CERRO OCUCAJE}

\subsection{Ubicación y descripción del área geográfica}

La región de Ica, está situado en la costa sur del litoral peruano, a 306 kilómetros al sur de la capital, «Es el único de los departamentos qué está formado por planicies, también llamadas llanuras costeñas, puesto que la cordillera de los Andes se levanta muy al interior» (INGEMMET, 2010). En su geografía configuran variados pisos altitudinales como la Chala, Yunga, Quechua, Suni y Puna, su cota varía entre los 2 m s. n. m., en la zona de Paracas, Pisco, y los 3796 m s. n. m., en San Pedro de Huacarpana, Chincha.

En el espacio iqueño es posible diferenciar de manera genérica hasta tres conjuntos morfológicos, que se encuentran alineadas de forma paralela: El perfil costero; la amplia planicie costera; y las vertientes andinas. El plegamiento geológico sobre el cual se asientan los geoglifos, conforma la denominada cordillera costera, "constituida por una alineación de cerros de moderada elevación» (INGEMMET, 2010; 2011), y qué de acuerdo a la toponimia se conoce como Cerro Ocucaje (Chuquihuaccha y Palomino, 2018). La provincia de Ica está constituida por los distritos: La Tinguiña, Los Aquijes, Ocucaje, Pachacutec, Parcona, Pueblo Nuevo, Salas, San José de Los Molinos, San Juan Bautista, Santiago, Subtanjalla, Tate, Yauca del Rosario, e Ica, así pues, el área en estudio comprende particularmente el extremo norte del valle bajo de Ica y geopolíticamente abarca el distrito de Ocucaje (ver figura 01 y 02).

\footnotetext{
1.Remotely Piloted Aircraft System. El Ministerio de Transportes y Comunicaciones, a través de la Dirección General de Aeronáutica Civil (DGAC), es el ente encargado de regular los requisitos y limitaciones para las operaciones de los sistemas de aeronaves piloteadas a distancia (RPAS).

2. Sistema de Información Geográfica (SIG): Google Earth.
} 


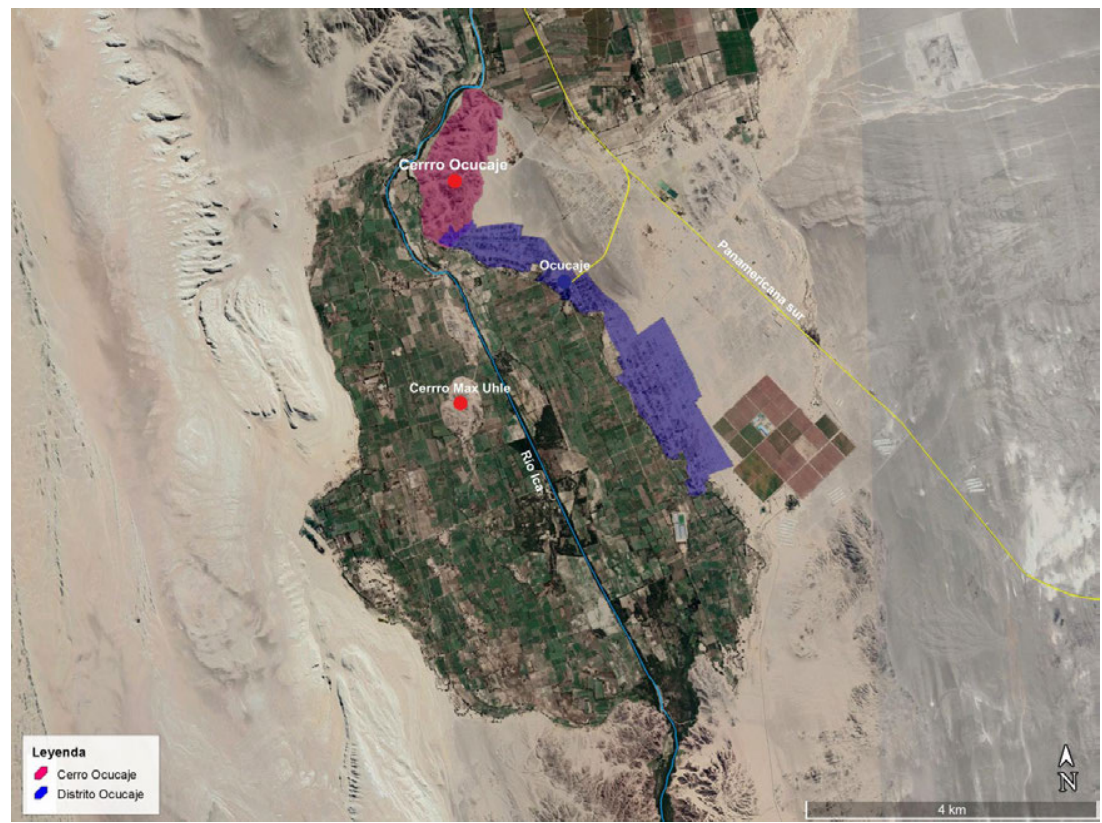

Figura 1. Vista satelital del sector norte del valle bajo de Ica (Adaptado de Google Earth).

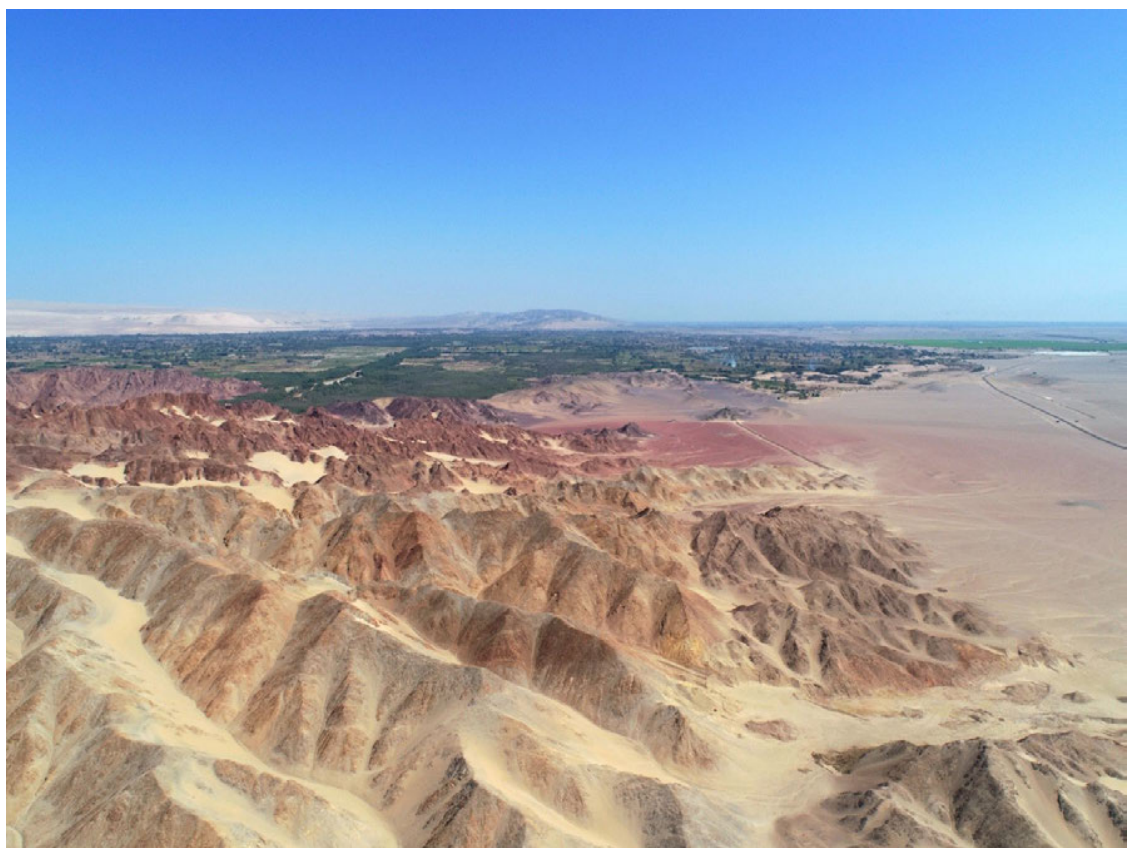

Figura 2. Entorno geográfico del valle bajo de Ica-Ocucaje. El paisaje representa parte de la cordillera costera y el fondo de valle, el contraste entre el tono rojizo-grisáceo y la alfombra verde, es sobresaliente en pleno desierto. 


\subsection{Antecedentes de investigación}

Los antecedentes sobre los geoglifos de la costa sur, tiene como referente pionero a Toribio Mejía Xesspe (1939), quien en 1926 y 1927 estando en Nasca, participo en un proyecto de excavaciones arqueológicas con el doctor Julio C. Tello. Mejía Xesspe, se interesó en «Los Puquios o Acueductos y Los Seques y Caminos religiosos», dándolas a conocer en el Congreso Nacional de Americanistas de 1939, las identifico como «seques» o caminos religiosos, y las describe como rayas o hileras que ocupan los lugares llanos y espaciosos, de las terrazas aluviónicas de los valles y mesetas de los tablazos. Identifica dos tipos de geoglifos que denomina como calles o avenidas, y canales o surcos, pensaba que se trataba de caminos rituales o ceremoniales, como los seques del imaginario de los incas.

Paul Kosok (1941), postula la tesis «El libro más grande de astronomía del mundo», ensayando de esta forma, uso y función. Hizo observaciones de los geoglifos desde 1939, organizo su hipótesis a partir de la observación, se percató que una de las líneas permitía fijar la puesta del sol en el solsticio de invierno, es así que con la observación y estudios básicos apoyados en la fotografía aérea, logro constatar que algunas líneas tenían una proyección solsticial, pudo identificar algunas con dirección equinoccial y pensó que las líneas habrían servido para el trazado de los movimientos de los astros, y el marcado de fechas importantes en la agricultura, como la llegada del agua, -recurso vital en esta región hasta hoy en día-y el preludio de la fertilidad de las tierras para la siembra.

María Reiche (1941), matemática alemana quien había acompañado a Kosok, continúo con los estudios de estas misteriosas marcas, manteniendo el postulado de su predecesor. Añadió que podía identificar determinadas constelaciones en las figuras de la pampa de Nasca, así entonces son ellos quienes posteriormente las nombran como geoglifos. Desde aquel momento y por mucho tiempo se pensó que servían como calendario astronómico. Reiche, constato la orientación solsticial de algunas líneas observando la salida y puesta del sol, además logró identificar tres formas de dibujos, las líneas alargadas absolutamente rectas, las pistas de forma trapezoidal, y las figuras formadas por trazos curvos.

Hans Horkheimer (1947), motivado por las investigaciones anteriores, comienza su estudio en 1945 y 1946, apoyado por la Universidad Nacional de Trujillo y la Fuerza Aérea del Perú. Como resultado de su investigación distingue tres clases de huellas: Plazoletas, que tienen formas triangular, trapezoidal, rectangular, mixta e irregular; Rayas, de longitud entre pocas decenas de metros y hasta kilómetros, y de $40 \mathrm{~cm}$ a $100 \mathrm{~cm}$ de ancho; y Figuras, de líneas continuas y contornos apenas visibles. También identificó montículos de piedras asociados a las plazoletas, construcciones, y tumbas cercanas a los geoglifos. Su interpretación sobre los tipos de huellas fue: « $1^{\circ}$ Las plazoletas, eran destinadas a reuniones sagradas, especialmente 
para el culto de los muertos. Los grupos que se reunieron eran diferenciados por su descendencia. $2^{\circ}$ Las rayas, son líneas genealógicas que determinaron el origen y relaciones de parentesco de los grupos reunidos en las plazoletas. $3^{\circ}$ Las figuras, tienen finalidad coreográfica; fueron utilizadas para las danzas sagradas de los grupos» (Horkheimer, 1947).

Rossel Castro (1977), se interesó por las Líneas y geoglifos de Nasca, les había prestado atención desde 1941 a 1945, cuando vivió en Nasca siendo párroco, más tarde en 1977 plasmó un libro titulado "Arqueología de la costa sur», ahí realizó una clasificación e interpretación de las figuras geométricas. Primer grupo: Proyecto de irrigación y parcelación agraria, corresponden a las figuras geométricas de la pampa y habrían servido para conservar humedad y fertilidad, con el uso del guano y otros fertilizantes. Segundo grupo: Los túmulos, son montículos de piedra que se acumulan dentro o fuera de los geoglifos, distingue cuatro tipos, cuadrangulares, rectangulares, cónicos y ovoides. Tercer grupo: Estilizaciones de orden textil, comprenden plazoletas, rayas y líneas que se combinan intencionalmente para representar signos de orden textil, trama, urdimbre y ovillo con aguja. Cuarto grupo: Los observatorios astronómicos, según Rossel, estos se sitúan en las quebradas donde ha surgido la agricultura, desde allí se podía observar eventos lunares, solsticiales y estaciones del año, menciona a Pinchango, Llipata, Achaco y Cahuachi, destacando al «observatorio Cahuachi».

Persis Clarkson (1990), tomó especial interés a los artefactos culturales dispersos en la Pampa de Nasca, consideró que estos eran claves para saber sobre quién y cuándo las visitaron, centró su investigación en el registro de miles de fragmentos de cerámica. Encontró restos de vasijas nasca dispersa en toda la pampa, supone todas de uso ceremonial, la mayoría era policroma, cuencos evertidos, vasos, platos, jarras y botellas de doble pico decorados con aves, peces, plantas y cabezas humanas. Clarkson, critica el trabajo de Rossel, considera que es poco sistemático y que sus datos no son confiables (ubicación altamente imprecisa).

Helaine Silverman (1990; 1993; 2002), había realizado exploraciones y estudios en Nasca desde 1983, centrando su investigación en Cahuachi, sus exploraciones en los valles El Ingenio y Río Grande inició entre los años 1988 y 1989. Como resultado de sus trabajos dio a conocer que los geoglifos no solo se encuentran en las pampas sino también a lo largo de los valles, donde en muchos casos están directamente asociados con asentamientos de la cultura Nasca. Para Silverman el concepto de geoglifo debe ser analizado y asocia su origen a la cultura Nasca, «trata el tema de los geoglifos como parte de la formación social nasquense [...] Discute el papel que este tipo de obras pudo tener en un contexto social que ella asocia a un desarrollo urbano que tuvo como centros nucleares a Cahuachi (Nasca) y Ventilla (Ingenio), justo en la época de mayor producción de geoglifos» (Lumbreras, 2000). 
Anthony F. Aveni (1990), tuvo su primer encuentro con los misteriosos dibujos de la llanura árida en 1977, luego de una temporada de campo en Cusco estudiando alineamientos astronómicos del sistema de «seques». Sus investigaciones en Nasca durante el año 1990, consolidan su planteamiento, supone que los centros radiados y trapezoides sirvieron para ser caminados, donde se realizaron algún tipo de ritual vinculados a la obtención del agua. Encuentra un nexo entre los centros radiados y el agua, explica que por alguna razón los centros están claramente ubicados en puntos estratégicos, donde el agua llega a los ríos, de este modo nota que muchos de los trapezoides están directamente relacionados a los centros de línea.

Johan Reinhard (1996), plantea «Montañas, agua y fertilidad». Considera que estos elementos estaban, y aún están estrechamente vinculadas a las creencias tradicionales andinas. Hace semejanzas entre las Líneas de Nasca y las Líneas de Bolivia, estas últimas continúan siendo tratadas como caminos sagrados. Reinhard, sostiene que, «numerosos elementos de la iconografía Chavín se han encontrado en Paracas cerca de Nazca, y los textiles paracas exhiben una fuerte influencia Chavín [...] Muestra, además, algunos geoglifos antropomorfos, uno de los cuales lo atribuye tentativamente a Paracas» (García, 2013, p. 152).

Como se ve, hasta mediados de la década de los noventa, los variados trabajos y propuestas mantienen la misma tendencia, y se distinguen solo en unos pocos aspectos. «Los geoglifos se interpretan como líneas de unión o indicadores de sitios sagrados, en conexión con cultos al agua y la fertilidad» (Rostworowski, 1993; Johnson, 1999; Reindel, 2006). Así las numerosas investigaciones sobre geoglifos estuvieron concentrados mayormente a la Pampa de Nasca y los trazos y figuras de la cultura nasca, «las propuestas sobre su uso y función son resumidas e incluidas por Karsten Lambers, dentro de lo que él denomina un Modelo Andino» (García, 2013).

En 1996, Markus Reindel y Johny Isla (1999), inician el Proyecto Arqueológico Nasca-Palpa, enfocado a los valles Río Grande, Palpa y Viscas. «El proyecto estuvo originalmente orientado en documentar los geoglifos de la cultura Nasca, y todos los posibles rasgos asociados. Entre los importantes resultados y aportes novedosos de la investigación, resalta el primer registro científico de geoglifos paracas del área de estudio» (Reindel et al. 1999; 2006; Lambers, 2006; García, 2013).

Lumbreras (2000), hace una síntesis de los escritos sobre los geoglifos de Nasca y Palpa, presenta y discute el descubrimiento de geoglifos paracas, mayormente antropomorfos. Sus conclusiones sobre las imágenes de la Pampa de Nasca son: «No hay ningún diseño que pueda asociarse con épocas previas a Nasca 1. Sin embargo, admite que hay algunos geoglifos más antiguos, en particular destaca el ave que se parece a los diseños «chavinoides» de los textiles de Karwa, incluso dice que las figuras humanas identificadas por el Proyecto Arqueológico Nasca-Palpa, son similares al de los tejidos Paracas Cavernas» (García, 2013, p. 152). 
Desde el 2010, Masato Sakai y Jorge Olano Canales (2014), vienen desarrollando el Proyecto de Investigación Arqueológica de las Líneas y Geoglifos de las Pampas de Nasca. El proyecto tiene como meta, registrar, analizar, y datar los geoglifos a partir de la cerámica emplazada en la pampa. Un dato interesante, es que «en varios de los centros de líneas se ha registrado cerámica Paracas Tardío» (García, 2013, p. 153). Y se han descubierto figuras antropomorfas que traen a la memoria al «Ser Oculado»

En el valle de Ica, durante las décadas de los 70, 80 y 90 se realizaron investigaciones específicas de reconocimiento arqueológico, en la parte baja, media y alta del valle de Ica. Estas exploraciones consiguieron revelar varios geoglifos en los distritos de San José de Los Molinos, San Juan, La Tinguiña, Santiago y Ocucaje (Williams y Pazos, 1974; Cook, 1988; 1990). Los informes e investigaciones hasta este punto solo mencionan unos pocos geoglifos en el valle de Ica, las descripciones se limitan a referirlas como caminos y rayas, no obstante, por las características relatadas estas trazas pertenecerían a la cultura Nasca.

Recientemente desde el 2006, existen unos escasos informes y reportes, donde se menciona la presencia de geoglifos atribuidos a la cultura Paracas. Rubén García (2013), describe dos grupos de geoglifos, Cerro Lechuza en Paracas, Pisco, y Cerro Pico en el valle de Yauca del Rosario, Ica. Las figuras descubiertas presentan características estilísticas de varias fases de la cultura Paracas: «Señala que los geoglifos de Cerro Pico, sirvieron para orientar a transeúntes en sus desplazamientos a los diferentes asentamientos del valle, y por sus características topográficas pudieron haber sido también objeto de veneración» (García, 2013).

De otra parte, la literatura arqueológica sobre Cerro Ocucaje, es limitada, solo Anita Cook (1988; 1990), reporta cuatro geoglifos en él, y Carlos Williams y Miguel Pazos (1974), informan de cementerios, caminos, viviendas, terrazas y aldeas contiguas. Poco antes, Alberto Rossel Castro (1977), reporta unos geoglifos, al parecer se trataría de las rayas reconocidas por Williams y Pazos (1974) en Cerro Piscontes. Así, a pesar de los valiosos escritos, nuestros predecesores no notaron los geoglifos figurativos que ostenta Cerro Ocucaje (Williams y Pazos, 1974; Rossel, 1977; Cook, 1988; 1990).

\subsection{Documentación, prospección y fotogrametría}

El registro de geoglifos resulta siempre dificultoso por su condición frágil. Expuestos perennemente sobre el pavimento desértico, afrontan siempre al medio natural y a la acción antrópica. El solo hecho de caminar sobre ellos dejan marcas que difícilmente se pueden borrar, no obstante, debido a la buena visibilidad desde cierta altura y a la ausencia de vegetación, la fotografía aérea con RPAS nos pareció un buen soporte técnico para el registro de los geoglifos. En el marco del trabajo de tesis, Geoglifos: Paracas y Nasca en el valle medio de Ica, y recientemen- 
te del Proyecto Arqueológico Geoglifos de Ica, se documentaron los geoglifos de Cerro Ocucaje (Chuquihuaccha y Palomino, 2018).

Según David Saez y Ana Beltrán (2015), en el Congreso sobre los Drones Aplicados a la Ingeniería Civil y en la Guía sobre los Drones y sus Aplicaciones a la Ingeniería Civil:

La fotogrametría es una técnica para determinar las propiedades geométricas de los objetos y las situaciones espaciales a partir de imágenes fotográficas. El concepto de fotogrametría es: "medir sobre fotos". Si trabajamos con una foto podemos obtener información en primera instancia de la geometría del objeto, es decir, información bidimensional. Si trabajamos con dos fotos, en la zona común a estas (zona de solape), podremos tener visión estereoscópica o, dicho de otro modo, información tridimensional. Básicamente, es una técnica de medición de coordenadas 3D, que utiliza fotografías u otros sistemas de percepción remota junto con puntos de referencia topográficos sobre el terreno, como medio fundamental para la medición. La fotogrametría aérea, se ha realizado habitualmente desde aviones tripulados con un coste y unos requisitos técnicos muy elevados [...]. La aparición de los RPAS (SARP-DRONES), han propiciado la reducción de costes de toma de datos de forma muy considerable, y se ha demostrado que son muy útiles y con unas precisiones y resultados muy buenos. (p. 4)

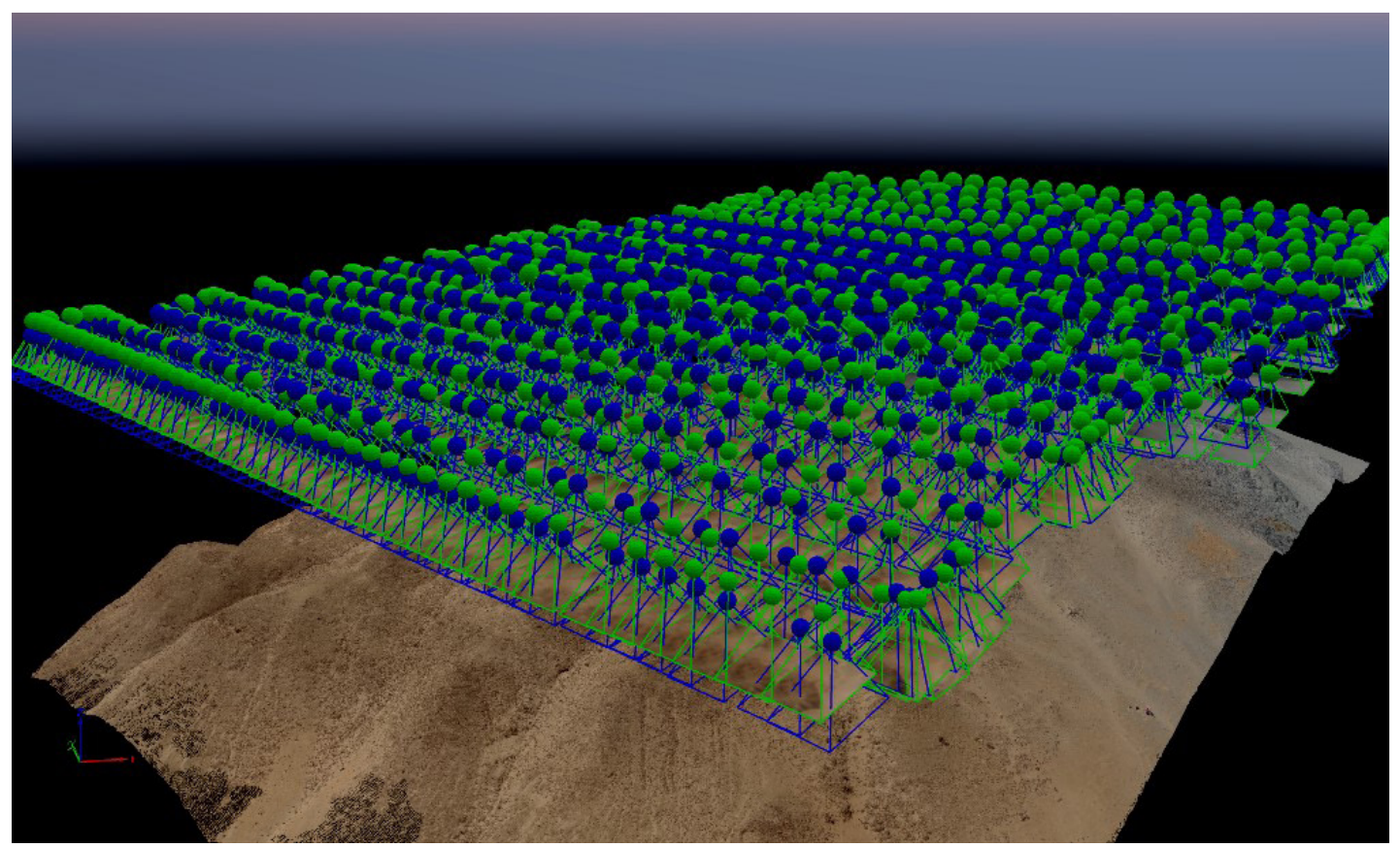

Figura 03. Levantamiento fotogramétrico de los geoglifos de Cerro Ocucaje (lado sureste del cerro). 
La fotogrametría moderna en los últimos años ha progresado admirablemente, hoy por hoy el uso de sistemas de aeronaves piloteadas a distancia -RPAS-se usa con mayor frecuencia en los ámbitos comercial y científico, revolucionando la forma en que se obtiene información espacial del territorio. Recientemente en el país se viene usando en arqueología, de hecho, el Ministerio de Cultura adquirió una cantidad considerable de drones Inspire 1. La fotogrametría aplicada al registro de geoglifos, no únicamente ofrece una precisión muy alta, sino que con el adecuado proceso, se obtienen entre dos y seis centímetros de margen de error, horizontal y vertical, también genera ortomosaicos georreferenciados, modelo digital de superficie, modelado 3D, entre otros. Es así que no solamente registramos los geoglifos, sino que al mismo tiempo se obtiene el modelado digital de superficie del terreno fotografiado (topografía).

Durante la documentación, se desarrolló una metodología sistemática aplicada a la investigación arqueológica, está consistió inicialmente en la búsqueda satelital, a través del Google Earth, de este modo se logró identificar siete posibles figuras, de los que solo se confirmaron cuatro, adicionalmente con la prospección se reconocieron tres más, y como resultado de la fotogrametría tres figuras más. Se realizó la prospección y registro tridimensional, escrito, gráfico y fotográfico, con la finalidad de confirmar y corregir algunos datos que solo en campo se pueden obtener. Una vez recogida toda la información posible se procedió al dibujo técnico de los nuevos hallazgos. Como soporte técnico de las actividades de campo, gabinete y análisis de datos, nos ayudamos de software como Google Earth, Microsoft Office, Auto Cad, Free Maps Tolls, Corel Draw y PIX4D.

Ahora bien, mediante el uso de aeronaves piloteadas a distancia de bajo costo, Phantom 3 Advance y Phantom 4 Profesional, con cámaras de 12 y 20 pixeles respectivamente, y técnicas de fotogrametría y conocimientos actuales del software PIX4D, se obtuvo un mosaico compuesto de 900 fotografías aéreas, georreferenciadas en Datum WGS84 y modelado 3D del paisaje arqueológico de Cerro Ocucaje, así como una descripción de la cobertura del mismo. Para el levantamiento fotogramétrico de los geoglifos, se necesitaron fotografías claras de buena calidad, con solape alto de entre 75 y $85 \%$ para que el software pueda encontrar puntos en común entre las imágenes, por traste o buena textura (mientras mayor solape mejor precisión).

Una buena planificación de vuelo es fundamental para lograr una adecuada cobertura estereoscópica, tenemos que tener en cuenta ciertos valores para realizar satisfactoriamente el vuelo fotogramétrico, en nuestro caso el plan de vuelo se realizó a 80 metros de altura respecto al punto de despegue, y la toma de fotografías se ejecutó manualmente. El Área cubierta es $0.1716 \mathrm{~km}^{2} / 17.164$ ha, el tiempo de vuelo duro 35 minutos, se realizaron dos, las condiciones climáticas no fueron 
favorables durante el segundo vuelo debido al viento paracas, por ello, se nota dos contrastes en el ortomosaico. Una vez terminado el plan de vuelo se realizó el proceso completo de 900 fotografías con el software PIX4D. El reporte de calidad muestra imágenes medianas de 3126 puntos clave por imagen; conjunto de datos 900 de 900 imágenes calibradas (100\%), todas las imágenes habilitadas; optimización de la cámara 19.27\% diferencia relativa entre los parámetros iniciales y optimizados de la cámara interna; mediana coincidente de 789.225 coincidencias por imagen calibrada (ver figura 04).

\subsection{Cerro Ocucaje}

La carta nacional IGN 1: 100,000, hoja 29-I, asigna con el nombre de Cerro Ocucaje, a una colina de poca altura y de bordes suaves, localizado en el kilómetro 334 de la vía Panamericana sur, en el distrito de Ocucaje, provincia y región de Ica. El espolón geológicamente forma parte de las estribaciones del frente andino - una cadena de cerros que se elevan bruscamente sobre las pampas costaneras y la depresión hidrográfica, extendiéndose por ambas márgenes del valle- se caracteriza por presentar un relieve suave a moderado, parcialmente cubiertos por gruesos depósitos de arena eólica (INGEMMET, 2010). La posición geodésica de referencia UTM WGS84 es: 426236E-8415066N a 435 m s. n. m., y ocupa una extensión estimada de 153 hectáreas.

«Ocucaje» según José Hernández Calderón, un lingüista iqueño, muestra su testimonio en dos fonemas quechuas: Uku que quiere decir «al fondo», y Kasqa equivale a «profundo o adentro». En cambio Juan Pardo Cornejo, cree se origina de las voces: Uco que significa «bajo o profundidad» y Jaja semeja decir «peña grande». De otro lado, pese a que fonéticamente Occachi se aleja de la homofonía Ocucaje, el profesor Medardo Aparcana Hernández, dio como significado «entre cerros». Hasta ahora las propuestas relacionadas al vocablo Ocucaje están conexas al idioma quechua, pretendiendo alcanzar un significado toponímico. Alberto Rossel Castro (1977), sostiene: «antes muchos nombres originarios han sido castellanizados y adulterados, otros han desaparecido por reemplazo de nombres posteriores» (p. 54). No obstante, la expresión Ocucaje parece hacer referencia a la particularidad morfológica del medio geográfico, Cerro Ocucaje como marcador geográfico sobresale de entre la pampa y la depresión hidrográfica (ver figuras 05 y 06).

El paisaje cultural arqueológico Cerro Ocucaje, exhibe al menos 10 geoglifos figurativos. Por un lado, dibujos de personajes y animales fueron grabados en las laderas del lado sureste del cerro, de otro, restos de cerámicas estilísticamente relacionados a la alfarería Nasca Temprano, fueron dejados -como parte de actividades rituales- dispersos y contiguos a los geoglifos. Los afloramientos rocosos desprenden numerosas piedras angulares y subangulares (guijarros), los cuales fueron usados para formar los geoglifos a través de un único proceso constructivo, técnica positi- 


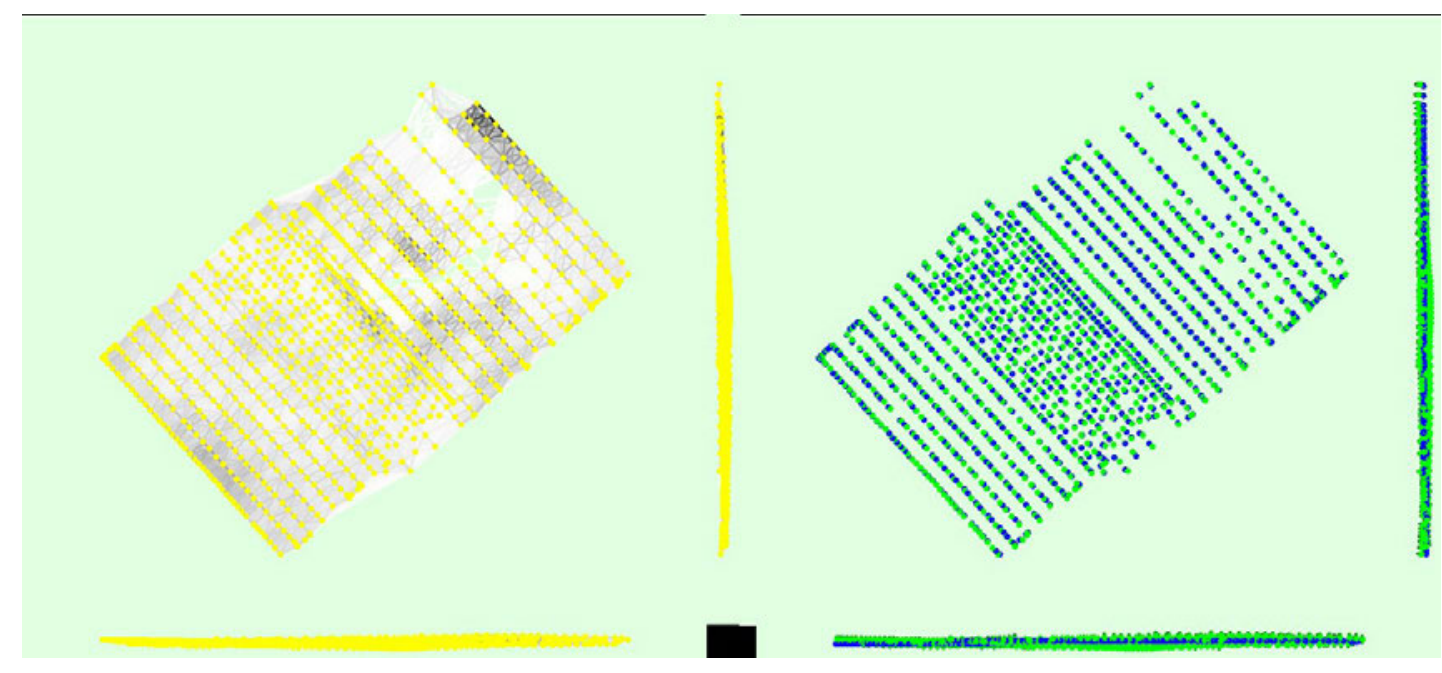

Figura 4. Imagen computada / GCPs / Posiciones de puntos de empate manual. Y posiciones de imágenes computadas con enlaces entre imágenes coincidentes.
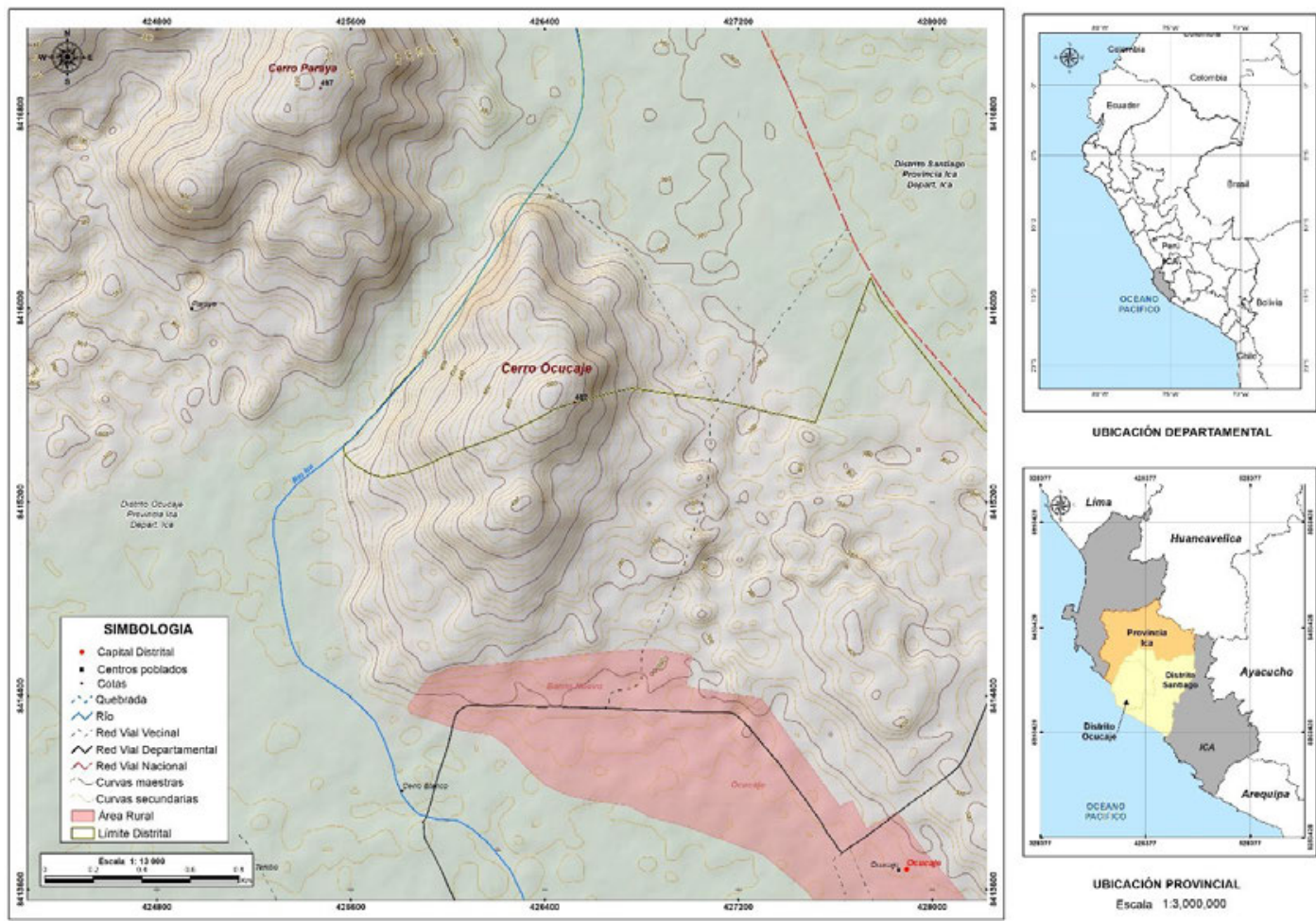

UTICACIÓN DEPARTAMENTAL

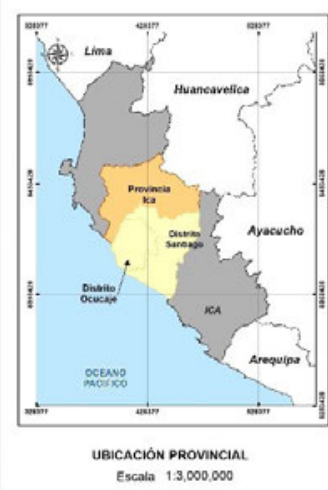

Figura 05. Mapa topográfico y de ubicación de Cerro Ocucaje. 


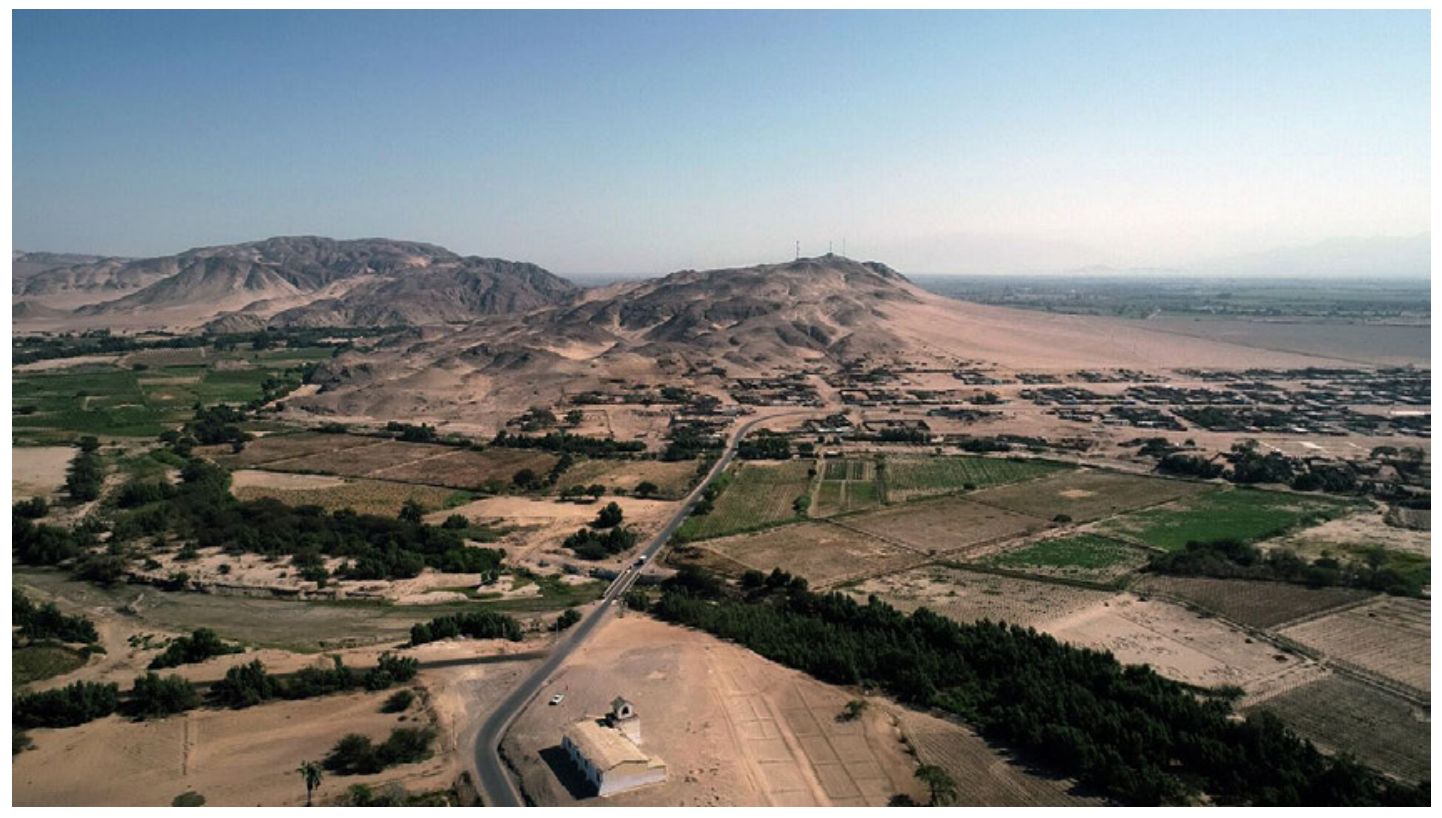

Figura 06. Vista panorámica de Cerro Ocucaje, contiguo al valle y río Ica.

va, esta práctica consistió en adicionar pequeños guijarros grisáceos en los espacios del trazo dónde se quiso acentuar las fisionomías de un personaje o animal, previamente delineado. De esta manera se adquiere una figura sólida sobresaliente. Aunque el atributo dominante es el sólido amontonamiento de gravas (forma), varios diseños contienen en su interior pequeñas áreas claras que fijan la imagen por el contraste oscuro sobre el suelo claro (fondo). El material constructivo mayormente es traído, sustraído del área que rodea la imagen, y en menor proporción del interior de la figura, por esta razón está es siempre clara a pesar de que el entorno geológico sea de tono grisáceo.

Geoglifo 1: Diseño de un «Ave» aparece en postura de frente con alas extendidas, cabeza vuelta hacia el lado izquierdo, y cola explayada; mide 17 metros de ancho y es visible desde una pequeña elevación, 110 metros al sur. De la traza acentuaron las alas y la cabeza, restando material a las secciones menores, de esta manera, porciones limpias en forma de cuadradillos resaltan claros en la imagen. No obstante, el diseño se delineó primariamente con la adición uniforme de guijarros grisáceos, así se logró una figura sólida en alto relieve.

Geoglifo 2: Representación de un «Músico» una figura sólida en alto relieve. Aparece en un solo cuerpo, en postura frontal, parado, y brazos flexionados hacia la cintura. Sobre él, al lado izquierdo, aparece un objeto de aspecto geométrico, posi- 
blemente se trate de un tambor o una antara. El personaje mide 9 metros de largo, y es visible desde el suroeste, desde una elevación propia del espolón a 80 metros de distancia.

Geoglifo 3: El diseño simboliza a un «Agricultor» representado de pie, en postura de perfil, con las piernas semiflexionadas, brazos extendidos hacia delante, mientras a la vez sujeta un palo largo. La figura tiene 25 metros de largo, y se emplaza sobre una ladera de cerro de suelo pedregoso; se le puede ver desde una elevación rocosa situada al suroeste, a unos 70 metros. El diseño es una figura sólida en alto relieve, sin espacios claros en el interior.

Geoglifo 4: Se trata del dibujo de un ave «Lluthu» representado parado en dos patas, con el cuerpo de costado, cabeza circular con ojo redondo, pico abierto y lengua saliente. Del lado posterior del cuerpo se prolonga una cola, mientras de la parte inferior descuelgan las patas. De la figura sólo acentuaron el ojo, restando material del borde en forma circular, no obstante, el diseño resulta una figura sólida de un solo cuerpo en alto relieve, mide 26 metros de ancho y es visible desde los 130 metros, desde un pequeño afloramiento rocoso al sur.

Geoglifo 5: Representación del diseño «Concatenado» con circulo concéntrico. El dibujo sobresale del suelo como una figura en alto relieve, en positivo; construido mediante la adición uniforme de pequeños guijarros grisáceos. Mide 9.5 metros de ancho; y es visible desde el sur, a unos 125 metros (ver figura 07).

Geoglifo 6: Representación de un «Ave» en postura de frente con alas extendidas y cola explayada. El dibujo sobresale del suelo como una figura sólida en alto relieve; construido mediante la adición uniforme de pequeños guijarros grisáceos. En particular la figura es la más pequeña del lugar, tiene 8.5 metros de alto; y es visible desde el sureste, a unos 115 metros.

Geoglifo 7: «Canino» representado parado en cuatro patas con cuerpo de perfil, orejas levantadas y cola alzada en diagonal; mide 8.8 metros de ancho. La figura hace recordar al famoso perro de la Pampa de Nasca, empero, la técnica constructiva es distinta, el perro de Ocucaje es una figura sólida en alto relieve, hecho en positivo mediante la adición uniforme de pequeños guijarros grisáceos, fácil de ver desde un pequeño promontorio rocoso, situado al sureste a unos 88 metros de la figura.

Geoglifo 8: "Gato de las pampas» un felino en postura de perfil, en aparente estado de reposo, con cabeza semicircular, ojo redondo y orejas ovaladas. El rostro destaca por la predominancia del área clara, limpia. La figura fue hecha colocando pequeños guijarros grisáceos en las fisionomías que se quiso abultar, y sobre el trazo mismo, quedando la apariencia de una figura sólida de 18 metros de ancho, visible desde una pequeña colina, 70 metros al sureste. Lamentablemente las acciones antrópicas han afectado los ojos y boca (ver figura 08 y 09). 
Geoglifo 9: El motivo simboliza un ave «Cóndor» en posición heráldica. Aparece de frente con las alas extendidas, cabeza vuelta hacia el lado izquierdo, y cola explayada. De la figura acentuaron las alas y la cabeza, por el contraste oscuro de la forma y el tono claro del fondo. La figura fue construida mediante la adición uniforme de pequeños guijarros grisáceos, aplicándose material en las áreas físicas que se quiso destacar o abultar, es decir: el cuerpo, la cola, la traza de las alas, la cabeza y el ojo, como resultado del suministro se obtuvo una figura sólida en alto relieve. En definitiva, la figura es la más grande del lugar, mide 45 metros de ancho y es visible por un lado a partir del fondo de valle, y de otro desde una colina al sur a unos 140 metros.

Geoglifo 10: Una figura zoomorfa «Ave» colocada de frente con las alas extendidas hacia atrás, y cola bifurcada. En particular del diseño no se pudo distinguir la cabeza, aparentemente, se perdió durante un corte de terreno por acción antrópica, siglos atrás. No obstante, el ave aparece notoriamente en un solo cuerpo, como una sombra sólida saliente del suelo, mide 13.5 metros de largo, y es visible desde el suroeste, a partir de los 55 metros.

De las 10 figuras, cinco se reconocen como aves: Los Geoglifos 1 y 9 a juzgar por su disposición, están en actitud de vuelo con las alas extendidas; el Geoglifo 9 se identifica como un cóndor, Vultur gryphus llamado también cóndor andino, a menudo ha sido incorporado en cerámicas y textiles de la fase Paracas Tardío (Menzel, Rowe y Dawson, 1964, p. 380; García, 2013, p. 161). En el caso de los Geoglifos 4, 6 y 10 son diseños en una sola pieza, de apariencia abultada saliente del suelo; en particular el Geoglifo 4 parece representar al Lluthu (Arg: yutu), perdiz, Nothoprocta pentlandii, todavía recordado en contadas zonas de Perú como P’isaq, este animal aún está presente en la región quechua y ha sido muy valorado en tiempos prehispánicos.

El Geoglifo 10 parece relacionarse al Aeronautes andecolus, es decir, vencejo andino; el motivo aparece esencialmente en los ceramios Nasca, en los estilos Nasca 1,2 y 3.

Del grupo, cuatro geoglifos auscultan a mamíferos: Los Geoglifos 2 y 3 se distinguen como personajes antropomorfos. El Geoglifo 2, parece representar un músico paracas, similar a la vasija escultórica que exhibe el Museo Regional de Ica; el Geoglifo 3 es un agricultor, regularmente suele aparecer en la iconografía Nasca y en petroglifos paracas (Proulx, 2006, p. 9; Orefici, 2012). Los Geoglifos 7 y 8 son representaciones de animales cuadrúpedos: Un canino y un felino, respectivamente; el perro o Alqo es raramente representado, el único antecedente aparece dibujado en la Pampa de Nasca, no obstante, perros han sido encontrados en entierros Nasca en Cahuachi; el gato de las pampas, Leopardus colocolo llamado también gato moteado u Osqollo aparece regularmente en textiles paracas y en la alfarería Nasca Temprano.

Aunque la representación de las aves suele ser general, sin que unos detalles u otros suelan normalmente identificar claramente el tipo de ave concreto, la clara 
excepción a esto es la representación del cóndor, que aparece incluso como figura principal. Con frecuencia las imágenes de felinos aparecen como figura central, «casi siempre con atributos humanos y a menudo asociados a vegetales» (Arranz, 2009). Contrariamente, el felino de Ocucaje es una imagen sencilla carente de ornamentos, y de atributos sobrenaturales. Un aspecto importante de los geoglifos de cerro Ocucaje, en general, son representaciones naturalistas; los personajes carecen de rasgos mitológicos; y los animales de atributos humanos y ornamentos.

Los diversos geoglifos se presentan como parte del contexto del paisaje cultural arqueológico, y como segmento de una expresión sociocultural de los grupos sociales que ocuparon estos territorios, y que se demuestran a través de los diversos yacimientos arqueológicos ubicados en las márgenes laterales del río Ica. La ocupación del territorio como los cambios y fenómenos sociales, fueron intensos durante los periodos Paracas y Nasca. Cuando el estilo topara inició su influencia en el valle alto, durante la fase transicional Paracas-Nasca, el valle acababa de sufrir una reorganización dramática causada por el colapso de la antigua estructura (Paracas Necrópolis). El valle medio sufrió una descentralización y una dispersión de la población a sitios pequeños, situados en las laderas altas y cimas de los cerros en terreno difícil.

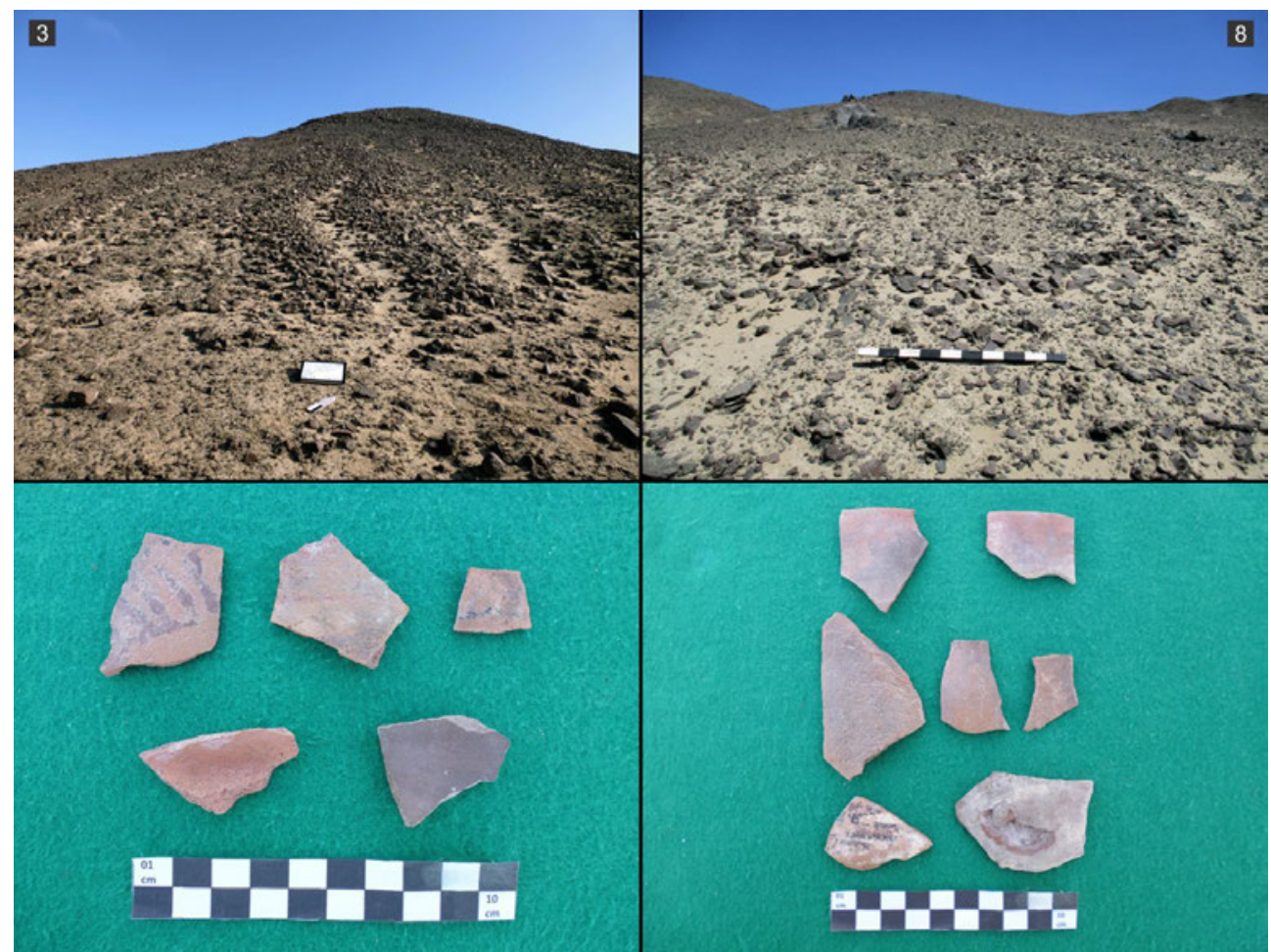

Figura 07. Vistas en detalle de los geoglifos 3 y 8 , nótese el proceso constructivo en positivo (ver forma y fondo). Véase también fragmentos de cerámica contiguos a los geoglifos 9 y 10. 


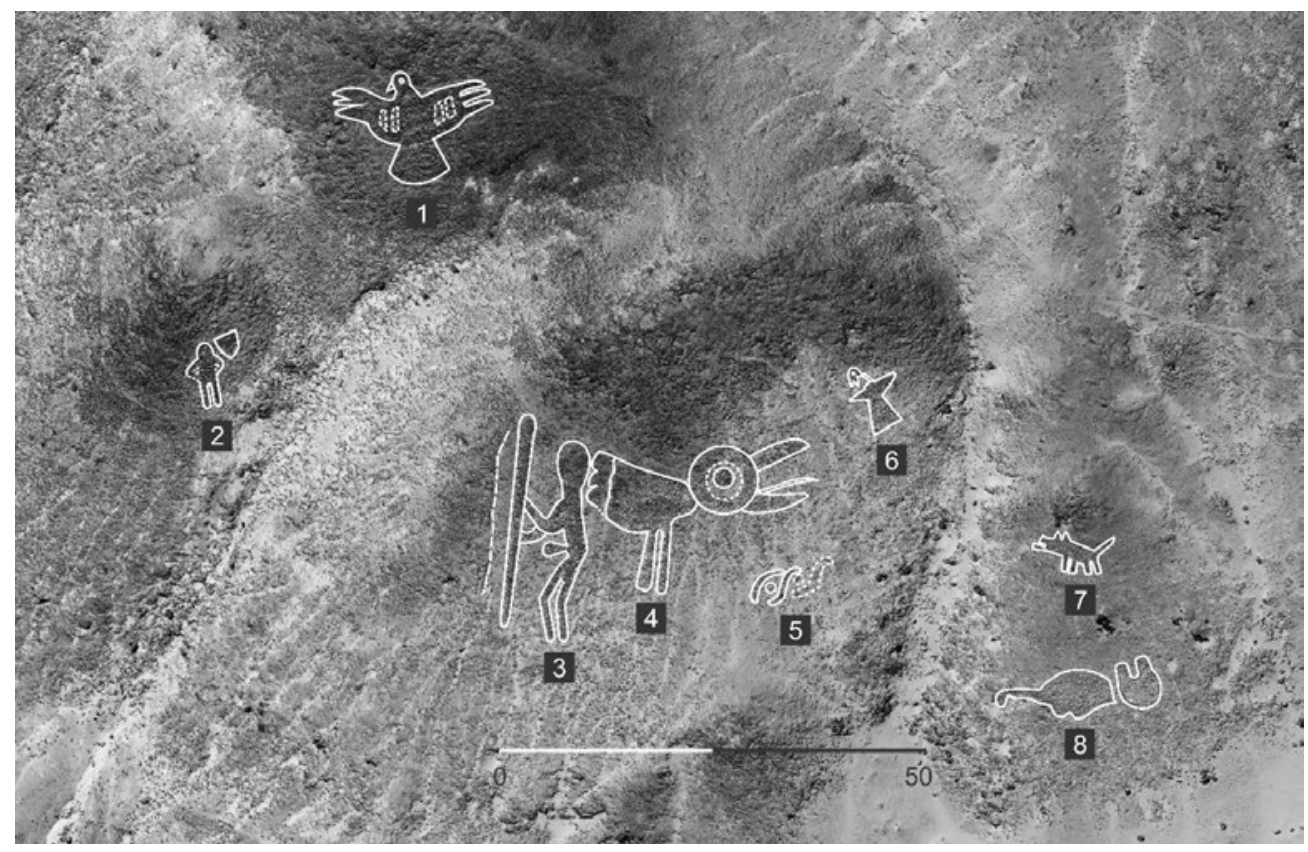

Figura 08. Geoglifo 1, ave; geoglifo 2, músico; geoglifo 3, agricultor; geoglifo 4, lluthu; geoglifo 5, concatenado con circulo concéntrico; geoglifo 6, ave; geoglifo 7, canino; y geoglifo 8, gato de las pampas.

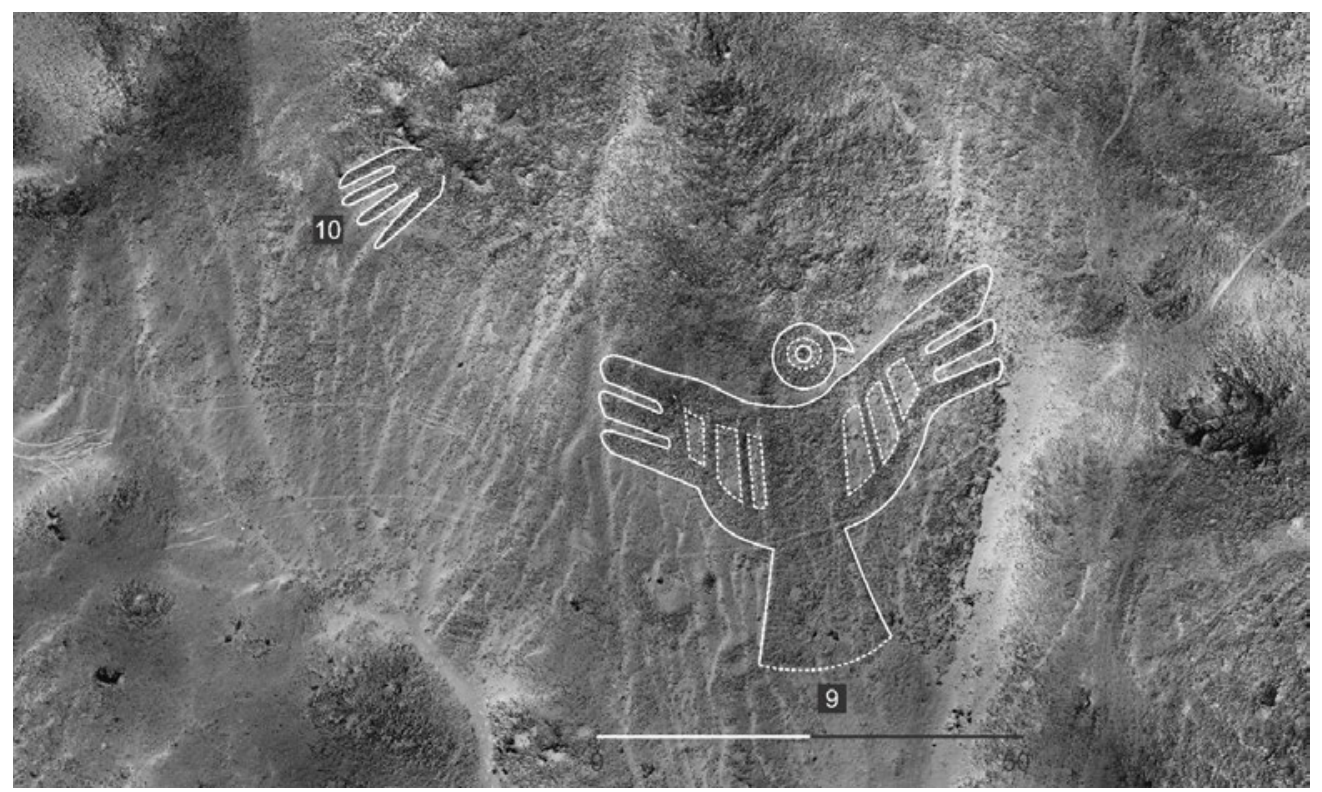

Figura 09. Geoglifo 9, cóndor; y geoglifo 10, posible vencejo. 
La difusión de cerámica proveniente de Ocucaje, y de sus convenciones estilísticas e iconográficas, a través del valle en la fase Ocucaje 10, sugiere que los grupos de Ocucaje asumieron el control regional dejado por la caída de Callango (Massey, $1980 ; 1982)$.

De otro lado, de las amenazas para la preservación de los geoglifos: Las condiciones meteorológicas causan la erosión de las rocas, mientras las condiciones climáticas como el viento paracas, en ocasiones, cubre de arena el paisaje arqueológico, y en otras, las descubre. Estos escenarios durante siglos han alcanzado deteriorar las figuras, del mismo modo las acciones antrópicas provocan una serie de distorsiones del medio natural y cultural. Con el boom agroexportador los empresarios (agricultores) extendieron sus predios hacia las laderas de cerro, hoy por hoy, los fundos cubren las llanuras del valle y en la actualidad proyectan ocupar las laderas donde se asientan los geoglifos, ello expone peligrosamente los paisajes arqueológicos.

Frente al notable crecimiento de la agricultura, caso fundo Los Rubini, como de la ampliación de zonas rurales, caso Barrio Nuevo, y de la construcción de antenas de comunicación celular sobre Cerro Ocucaje, el trabajo de los funcionarios del INC hoy Dirección Desconcentrada de Cultura Ica, del Ministerio de Cultura - lleva instalada en la región desde 1972-, parece no ser suficiente. Alberto Rossel Castro, ya en la década de los 70, relata la destrucción de un sitio arqueológico de gran tamaño por ensanche de tierras de cultivo, estos hechos por omisión o desconocimiento hasta hoy parecen no haber mermado, en definitiva, estas dinámicas sociales representan el mayor peligro para la preservación de los geoglifos de Cerro Ocucaje.

\section{DISCUSIÓN DE RESULTADOS}

Las evidencias documentadas indican que los geoglifos de clase figurativo se construyeron sobre laderas de cerros de poca elevación, vinculados a la técnica positiva, y relacionados con la cultura Paracas. La iconografía de las figuras de Cerro Ocucaje estilísticamente se cataloga con la alfarería de los estilos Ocucaje 8, 9 (Paracas Tardío) e incluso con Ocucaje 10 y Nasca 1 (transición Paracas-Nasca). La literatura arqueológica indica que, «Paracas fue la primera sociedad de la costa sur de los Andes centrales en adoptar estilos de arte complejos a nivel regional, construir poblados con arquitectura publica significativa, crear complejos sistemas de intercambio interregional» (Paul [ed.] 1991; Silverman, 1996; Isla y Reindel, 2007; Proulx, 2008; Van Gijseghem y Vaughn, 2008; Tantaleán, Stanish, Zegarra, Pérez y Nigra, 2004, p. 32).

Los geoglifos de Cerro Ocucaje, presentan características iconográficas y constructivas, similares a otros elementos semejantes a nivel local y regional, por lo que su datación está dada a partir de su semejanza estilística con el corpus iconográfico Paracas, Nasca, así como en el periodo Horizonte Temprano e Intermedio Temprano, propuesto por el Proyecto Arqueológico Nasca-Palpa: «[...] Divide al período Pa- 
racas en tres fases: Paracas Temprano (800-550 a. C.), Paracas Medio (550-370 a. C.) Paracas Tardío (370-200 a. C.) y la fase de transición Paracas-Nasca o Nasca Inicial (200 a. C. -90 d. C.). Y al Periodo Nasca en tres fases: Nasca Temprano (90-325 d. C.), Nasca Medio (325-440 d. C.) y Nasca Tardío (440-620 d. C.)» (Unkel y Kromer, 2009, p. 235; Reindel, 2009). Estas fases han permitido hacer un mejor diagnóstico de la ubicación cronológica relativa de los geoglifos, tomando como indicadores las características iconográficas y constructivas.

La cerámica por su parte, cerámica Nasca Temprano, como indicador, aparece escasamente en pequeñas dispersiones. Es interesante considerar que a diferencia de los geoglifos de Nasca y Palpa, la cerámica no aparece directamente depositada sobre los geoglifos de Ocucaje, esto permite inferir primariamente sobre quienes las reconocieron y cuando las visitaron, sin embargo, ello no garantiza que se crearan durante esa época.

Otro aspecto importante de la investigación, es que se precisa la técnica constructiva, en positivo, estilo particular que como indicador cronológico caracteriza determinado momento histórico, fase o periodo, en ese sentido creemos que los conceptos de arte se ajustan a descifrar los patrones de diseño de los geoglifos, y en su efecto a distinguir si existe recurrencia constructiva. A diferencia de nuestros predecesores, planteamos que la adición uniforme de pequeños guijarros, técnica positiva, es el estilo más antiguo de construir geoglifos en toda la costa sur del Perú.

Existen geoglifos en casi toda la costa peruana, recientemente se ha reportado geoglifos en Quebrada Cosos, Arequipa, en cerro Huatocay, Lima, en pampa Colorada, Áncash, en cerro Campana entre los ríos Moche y Chicama, La Libertad, y naturalmente en Nasca, Palpa, Ica, Pisco y Chincha (León, 1996, p. 24; Echevarría y Corcuera, 2011, p. 294; López y Maquera, 2016, p. 107). Un dato extraoficial, menciona geoglifos en el valle de Caral, Lima. Estos datos nos hacen pensar que el origen de los geoglifos se da en la zona costera de los Andes centrales, por lo que es una tradición netamente costeña, en ese contexto, es muy posible que los geoglifos tuvieran su iniciación en la costa sur del Perú, en Paracas, Pisco, Ica, allí hay unos geoglifos con rasgos estilísticos chavinoides, hasta ahora los más antiguos (García, 2013, p. 153).

La interpretación de los geoglifos, es variada entre los investigadores, estos enfoques son resultados de investigaciones arqueológicas, etnográficas, e históricas. Entre las más conocidas destaca Paul Kosok (1965), postuló «el libro de astronomía más grande del mundo», mientras que María Reiche (1993), busco por décadas conexiones astronómicas y calendáricas, «la hipótesis astronómica fue sometida a varias pruebas que llevaron a resultados negativos» (Lambers, 2006). Sin embargo, Toribio Mejía Xesspe (1939), años antes había identificado los geoglifos como «seques» o caminos religiosos y pensó que se trataba de caminos rituales o ceremoniales. 
Según Rubén García (2013), «las propuestas sobre el uso y función son resumidas e incluidas por Lambers, dentro de lo que él denomina un modelo andino» (p. 153). Hasta este punto los geoglifos se interpretan como «líneas de unión o indicadores de sitios sagrados en conexión con cultos al agua y la fertilidad» (Reindel, 2006). Por lo expuesto, consideramos que a pesar del aspecto mitológico y ritual, circunscrito a los geoglifos, estos debieron cumplir función activa como indicadores de espacios de tránsito u orientación. Senderos, apachetas, paravientos y concentraciones de moluscos aparecen en los transeptos orientados hacia las playas (Obsidiana Consultores SAC, 2014). Este dato resulta interesante al pensar en corredores de tránsito entre el valle, la pampa desértica y la rivera litoral, la interacción entre las gentes del mar y el valle o viceversa, fue fluida. De hecho, grandes conchales se encuentran en el litoral asociado a estructuras construidas especialmente para la pesca. El consumo de moluscos se dio desde épocas tempranas, se ven en distintos sitios del valle e incluso llegaron hasta la zona alto andina.

La pesca fue una actividad especializada durante la época Paracas, el consumo de pescados y mariscos generó una economía de necesidad básica, por lo que necesitó de proveedores (pescadores). Concentraciones de moluscos se hallan en distintas partes de la pampa desértica, generalmente cercanos a paravientos, senderos y geoglifos. Las líneas y figuras establecieron mecanismos visibles de orientación y se fueron innovando en el tiempo. Los geoglifos figurativos en técnica positiva, guardan estrecha relación con los estilos alfareros Paracas Tardío y Nasca Inicial, los diseños se ubican por lo general sobre laderas de cerros pedregosos de poca elevación, personajes, aves y animales fueron representados orientados hacia el valle, siempre cerca de caminos antiguos o espacios de transitó, corredores naturales y quebradas.

Hasta ahora los académicos coinciden que los geoglifos son parte de la expresión de arte rupestre: «El arte es entendido generalmente como cualquier actividad o producto realizado con una finalidad estética y también comunicativa, mediante la cual se expresan ideas, emociones o, en general, una visión del mundo, a través de diversos recursos» (Anónimo). Creemos que los conceptos de arte (espacio positivo y negativo) se ajustan a precisar los patrones constructivos de geoglifos, y en su defecto a distinguir si existe recurrencia constructiva.

Los geoglifos son importantes marcadores del paisaje cultural en épocas tempranas, pese a que suelen ligarlas con la cultura Nasca, se sabe que también caracterizan a Paracas. Rubén García (2013), presenta algunos ejemplos del valle de Ica y Pisco; Henry Tantaleán et al. (2013), menciona unos en el valle de Chincha; Markus Reindel (2006; 2008), centro su trabajo en los geoglifos de Palpa; y recientemente Masato Sakai (2016), en Nasca, vienen registrando una gran cantidad de geoglifos. «De esta manera parecen existir en todos los valles del ámbito Paracas. Estos se fechan por razones estilísticas, puesto que se trata de representaciones figurativas, y se dejan 
comparar bien con ejemplos de Palpa» (Reindel, Isla y Lambers, 2006a; 2006b; Lambers, 2006, Reindel e Isla, 2008). Y con los de Cerro Pico, en Ica (García 2013).

Las figuras paracas, según Reindel e Isla (2006), «a diferencia de los afamados geoglifos de la cultura Nasca, que en su mayoría se emplazan sobre las mesetas planas, entre los valles y crestas de cerro, los geoglifos paracas fueron colocados por lo general en laderas de cerros, de manera que resultan visibles desde el terreno mismo» (p. 73). Sus dimensiones varían entre $2 \mathrm{~m}$ a $60 \mathrm{~m}$, son más pequeños que los geoglifos nasca, entre los motivos más representados se observan figuras antropomorfas en escenas de aspecto naturalista, y en el caso de las figuras zoomorfas se representan aves.

\section{CONCLUSIONES}

La investigación presenta datos preliminares del Proyecto Arqueológico Geoglifos de Ica, y los resultados fotogramétricos del sector sureste de Cerro Ocucaje. Según nuestros resultados: Los geoglifos tratados en el presente estudio, exhiben características iconográficas similares a los de Nasca y Palpa, por lo que se reconoce a la sociedad Paracas como la autora de estas expresiones durante el Horizonte Temprano, precisamente en la fase Paracas Tardío (370-200 a.C.) e incluso durante la fase de transición Paracas-Nasca (200 a.C.-90 d.C.). De los modos de manufactura se identificó una técnica productiva base, así tenemos, la técnica positiva, como tendencia prolífera de los geoglifos paracas del valle de Ica.

Agradecimientos: Quiero agradecer la cooperación de Álvaro Ruiz (Director General de DRONE COATZA), Antonio Peón (Director Área SIG GNSSY Pix4D en GEOSPACIAL SOLUTIONS SA DE CV), quienes gentilmente realizaron el levantamiento fotogramétrico de los geogligos de Cerro Ocucaje. Asimismo, mi gratitud y cariño por el incondicional apoyo, a mis amigos y colegas arqueólogos, que sin su ayuda no hubiera sido posible cumplir con los objetivos del estudio, por ello merecen mis más sinceros agradecimientos: Gysvel Nohely Palomino Inga, Marco Antonio Taquiri Gonzales, Ricardo Gonzales Alvarado, Frank Egort Medina Lizarbe, José Luis Quispe Orosco, Isaías Enoc Yáñez Córdova, y en especial a Raysa Rosalin Huillca Huanaco. Al Ministerio de Cultura del Perú, por otorgar los permisos para la realización de las investigaciones, así como a la Dirección Desconcentrada de Cultura Ica.

\section{REFERENCIAS BIBLIOGRÁFICAS}

Aveni, Anthony F. (1990). Order in the Nazca lines. En A. Aveni (Ed.). The lines of Nazca (pp. 41-113). Memoirs of the American Philosophical Society, 183, Philadelphia.

Aveni, Anthony F. (1986). The Nazca Lines: Patterns in the Desert. Archaeology, 39(4), 32-39. 
Clarkson, Persis B. (1990). The archaeology of the Nazca Pampa: environmental and cultural parameters. En A. Aveni (Ed.). The lines of Nazca (pp. 115-172). Memoirs of the American Philosophical Society 183, Philadelphia.

Cook, A. (1994). Investigaciones de reconocimiento arqueológico en la parte baja del valle de Ica. Informe final. Lima.

Chuquihuaccha, C. y Palomino, G. (2018). Geoglifos: Paracas y Nasca en el valle medo de Ica [tesis de licenciatura, Universidad Nacional San Luis Gonzaga]. Repositorio institucional UNSLG.

García, R. (2013). Geoglifos Paracas de la Costa Sur: Cerro Lechuza y Cerro Pico. Paracas: Nuevas Evidencias, Nuevas Perspectivas. En A. Bachir y J. Dulanto (Eds.). Boletín de Arqueología PUCP, 17, pp. 151-168. Fondo Editorial Pontificia Universidad Católica del Perú, Lima.

García, R. (2009). Puerto Nuevo y los orígenes de la tradición estilística y religiosa Paracas. Boletín de Arqueología, PUCP, 13, pp. 187-208.

García, R. y Pinilla, J. (1995). Aproximación una secuencia con fases con cerámica temprana de Paracas. Journal of the Steward Anthropological Society, 23 (1-2): 43-81. Urbana, Illinois.

Herrán, E. (1985). Geoglifos de Nasca. Nuevos Diseños, Nuevos Enigmas. Lima.

Horkheimer, H. (1947). Las plazoletas, rayas y figuras prehispánicas en las pampas y crestas de la Hoya de Río Grande. En: Revista de la Universidad Nacional de Trujillo, 2(1), 45-63.

Instituto Geológico, Minero y Metalúrgico (INGEMMET). (2010). Hidrología de la cuenca del río Ica. Boletín $N^{\circ} 3$ Serie H Hidrogeología. Lima.

Kosok, P. (1965). The Largest Astronomy Book in the World - New aspects of ancient Nasca. Chapter VI: Life, land and water in ancient Peru, pp. 49-62. Long Island University Press, New York.

Lambers, K. (2006). The geoglyphs of Palpa, Peru: Documentation, Analysis, and Interpretation. Forschungen zur Archäologie Außereuropäischer Kulturen 2. Linden Soft, Aichwald.

Lumbreras, L. (2000). Plan de Manejo de las Líneas de Nasca. Contexto Arqueológico (Volumen I). Convenio UNESCO-INC, Lima.

Makowski, K. (2017). Lo real y lo sobrenatural en las iconografías Paracas y Nasca. En Cecilia Pardo y Peters Fux (Eds). Nasca. Libro de la exposición Nasca en el MALI.

Massey, S. (1983). Antiguo centro Paracas-Ánimas Altas, en J. A. de Lavalle (Ed.), Culturas precolombinas: Paracas (pp. 134-160). Banco de Crédito del Perú, Lima. 
Mejía Xesspe, T. (1946). Acueductos y caminos antiguos de la hoya del Río Grande de Nasca. En: Actas y Trabajos Científicos del XVII Congreso Internacional de Americanistas (Lima 1939) Vol. I, pp. 559-569. Lima

Menzel, D. (1976). Pottery Style and Society in Ancient Peru. Art as a Mirror of History in the Ica Valley, 1350-1570. University of California Press.

Menzel, D. (1971). Estudios arqueológicos en los valles de Ica, Pisco, Chincha y Cañete. Arqueología y Sociedad 6. Lima: Universidad Nacional Mayor de San Marcos.

Menzel, D., Rowe, J. y Lawrence D. (1964). The paracas pottery of Ica a study in style and time. University of California press Berkeley and Los Angeles.

Proulx, D. (2006). Paracas y Nasca: culturas regionales sobre la costa sur de Perú.

Proulx, D. (1990). Nasca iconography. Originally published in French, German and Spanish. En Sergio Purin (Ed.), Inca-Perú: 3000 Ansd'Histoire (pp. 384-399). Gent (Belgium): Imschoot, uitgevers, 1990. Minor revisions with added illustrations 2007.

Reiche, M. (1976). Geheimnis der Wuste /Mystery on the desert / Secreto de la Pampa. 6ta edition. Sttugart.

Reiche, M. (1949). Los dibujos gigantescos en el suelo de las pampas de Nazca y Palpa. Editora Médica Peruana S.A., Lima.

Reinhard, J. (1987). The Nazca Lines. A New Perspective on Their origin and Meaning. Lima: Editorial Los Pinos.

Reindel, M. (2009). Life at the edge of the desert-Archaeological reconstruction of the settlement history in the Valleys of Palpa, Peru. En Marcus Reindel and Gunther A. Wagner (Eds.). New Technologies 337 for Archaeology. Multidisciplinary Investigations in Palpa and Nasca, Peru (pp. 439-461). Berlin: Springer-Verlag.

Reindel, M., Isla, J.y Lambers, K. (2006). Los Geoglifos de Palpa: Documentación, Análisis y Perspectivas. Boletín de Lima, 143, pp. 73-11. Lima: Editorial Los Pinos.

Reindel Marcus, Isla Johny y Tomasto Elsa. (2002). Proyecto Arqueológico Nasca - Palpa. Informe Final entregado al INC. Lima, junio 2002.

Reindel Marcus, Isla Johny y Koschmieder Klaus. (1999). Asentamientos prehispánicos y geoglifos en Palpa, costa sur del Perú. En Beitrage zur llgemeinen und Vergleichenden Archäologie, 19, pp 313-381. Verlag Philipp Von Zabern. Mainz am Rhein.

Reinhard, J. (1997). Las Líneas de Nazca. Un nuevo Enfoque sobre su Origen y Significado. Boletín de Lima. Tercera Edición en Castellano. Editorial Los Pinos, Lima. 
Rostworowski, M. (1993). Origen religioso de los dibujos y rayas de Nasca. Journal de la Société des Américanistes LXXIX: 189-202, París.

Rossel, Alberto. (1977). Arqueología sur del Perú. Editorial Universo S.A. Lima.

Sakai, Masato; Olano, Jorge; Matsumoto, Yuichi y Takahashi, Hiraku. (2010). Centros de Líneas y Cerámica en las Pampas de Nasca, Perú. Yamagata University Press, Japón.

Silverman, Helaine. (2002). Ancient Nasca Sttlement and Society. University of Iowa Press, Iowa City 52242.

Silverman, Helaine y Proulx, Donald. (2002). The Nasca. Blackwell Publishrs Inc.

Tantaleán, H., Stanish, C., Pérez, K. y Rodríguez, A. (2017). Las ocupaciones Paracas y Topará en Cerro del Gentil, valle de Chincha. Boletín de Arqueología PUCP, 22, pp. 61-89. Fondo Editorial, Pontificia Universidad Católica del Perú.

Wallace, D. (1991). A technical and iconographic analysis of Carhua painted textiles. En Anne Paul (ed.). Paracas Art \& Arquitecture. Object and Context in South Coastal Peru (pp. 61-109). Iowa City: University of Iowa Press.

Williams, C. y Pazos, M. (1976). Inventario, Catastro y Delimitación del Patrimonio Arqueológico del Valle de Ica. Lima: Instituto Nacional de Cultura.

\section{SOBRE EL AUTOR}

\section{Carls William Chuquihuaccha Huancahuari}

Licenciado en Arqueología por la Universidad Nacional San Luis Gonzaga. Diplomado en Metodología de la Investigación por la Escuela de Postgrado Neumann Business School. Diplomado en Derecho Administrativo y Gestión Pública por la Facultad de Ciencias Económicas de la Universidad Nacional Mayor de San Marcos. Operador-Piloto RPAS por la Dirección General de Aeronáutica Civil del Ministerio de Transportes y Comunicaciones. Actualmente presidente del Instituto de Paleontología, Arqueología y Medio Ambiente - IPAMA y director del Proyecto Arqueológico Geoglifos de Ica. 